瀬戸内海の浅海域における魚類幼期個体の出現特性

\title{
Characteristics in Occurrence of Fish Early Life Stages of the Shallow Waters of the Seto Inland Sea
}

\author{
小路 淳* \\ 厷島大学竹原水産実験所． $7725-0024$ 広島県竹原市港町 5-8-1
}

\section{Jun SHOJ*}

Takehara Marine Science Station, Setouchi Field Science Center, Hiroshima University, 5-8-1 Minato-machi, Takehara, Hiroshima 705-0024, Japan

\begin{abstract}
Species composition of fish early life stages was compared among different habitats in shallow waters of the Seto Inland Sea. Data from monthly surveys in three habitats (offshore area, inshore area, and fishing port) in the Sea of Hiuchi, central part of the Seto Inland Sea, during the late 1990s was analyzed. In total, 51,322 fishes belonging to more than 97 taxa in 49 families were collected with a larva-net at eight offshore sampling stations. 9,521 fishes belonging to more than 38 species in 24 families were collected with a small-triangle net at 10 inshore stations, and 13,561 fishes belonging to more than 44 species in 26 families were collected by light-trap sampling in the fishing port. The ichthyofauna of the three habitats was diverse and abundant from late spring to early summer. Differences in the composition of the dominant species among the three habitats indicate that each habitat serves as a nursery for different fish species. Intra-habitat comparison of fish species in summer between inshore stations without vegetation (i.e., sandy beaches) and those with vegetation (i.e., seagrass or macroalgal beds) showed a significant effect of vegetation on dominant fish species composition. The differences in composition of young fish species among the habitats indicate that integrated conservation of the different fish habitats in shallow waters is indispensable for sustainable use of fishery resources in the Seto Inland Sea.
\end{abstract}

Key Words: benthic vegetation, fish early life stages, fisheries management, nursery grounds, Seto Inland Sea, shallow-water ecology, species composition

\section{はじめに}

魚類は浅海域における食物連鎖の構成者であると同時 に, 沿岸域に暮らす人々の食糧資源としても重要な役割を 果たす. 浅海生態系の機能特性を把握し，その保全や持続 的利用を達成するためには, 現存する魚類の種組成, 生物 量, 食性およびそれらの時空間的変化を定量的に把握する ことが不可欠である.

瀬戸内海は, 魚介類の生産力が世界の内湾域の中でも最 る高い海域の一つである（岡市ら 1996）。このような高い 生産力を支える場として, 瀬戸内海では過去にアマモ場や 砂浜海岸が注目され，これらの場が魚類の成育場として果 たす役割について数多くの研究が行われてきた（東 1981; Yamamoto \& Tominaga 2005). しかしながら, 瀬戸内海に はアマモ場や砂浜以外にもガラモ場や人工海岸のような, 魚類にとって多様な生息環境が存在しているため, 魚類成 育場としての浅海域の機能を包括的に評価するためには，

Received 28 Dec. 2006 Accepted 5 June 2007

*
さまざまな生息環境で魚類群集の調查を行い，それぞれの 特性を比较検討する必要がある.

本研究では，水深 $30 \mathrm{~m}$ 以浅の水域を浅海域と定義し （環境省による定義では水深 $10 \mathrm{~m}$ 以浅が浅海域; 環境庁 1998)，1990 年代に瀬戸内海中央部の沖合域 (水深約 10-30 $\mathrm{m}$ ), 沿岸域（水深約 $1 \mathrm{~m}$ 以浅），および漁港（水深約 2-5 m）という環境条件が異なる3つの生息圈において魚類幼 期個体を主対象として行った周年サンプリングの結果を総 括する．３つの生息圈で出現する魚種を比較することによ り, 各生息圈における種組成およびその季節変動の特性を 明らかにすることを目的とした，さらに，沿岸域の定点を 植生の有無により 2 つ生息環境（藻場, 砂浜海岸）に分 類し, 植生の有無が夏期に出現する魚類幼期個体の種数お よび種組成に及ぼす影響を調查することを目的とした。

\section{材料と方法}

1996-1999 年に瀬戸内海中央部の煫灌（ひうちなだ）にお いて行った一連の調查により得られた標本を解析に用いた。 調查対象としたのは, 沖合域（水深約 10-30 m) の 8 定点, 沿岸域（波打与際：水深約 $1 \mathrm{~m}$ 以浅）の 12 定点および漁港 


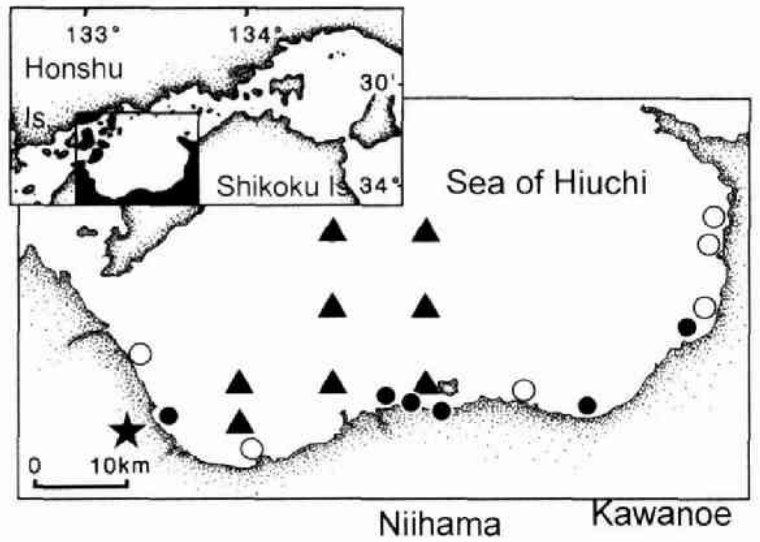

Fig. 1. Map showing sampling stations in the Sea of Hiuchi, the central Seto Inland Sea, where monthly collection of larval and juvenile fishes was conducted from 1996 to 1999. Triangles: offshore area sampled with a conical larva-net from November, 1997, to October, 1998; open and closed circles: inshore areas without vegetation (sandy beach) and with vegetation (seagrass or macroalgae), respectively, sampled with a triangle-net from March, 1996, to February, 1997; asterisk: a fishing port for light-trap sampling from March, 1996, to March, 1999.

（水深約 2-5 m) の 1 定点である (Fig. 1). 冲合域, 沿岸域掠 よび漁港に扔ける調查結果の詳細はそ机ぞれ小路ら (2002), 小路・田中 (2002) および小路 (2000) に示されている.

沖合域での調查を 1997 年 11 月から 1998 年 10 月に煫灘 中央部の 8 力所の定点（水深約 $10-30 \mathrm{~m}$ ) において毎月 1 回行った．鰂の採集には口径 $1.3 \mathrm{~m}$ の稚魚ネット（目合 ( $0.5 \mathrm{~mm})$ を用い, 海底直上から水面までの傾斜曳きを船 速 2 knotで行った，後述する沿岸域および漁港における調 査結果との比較に 1 年分の調査結果をまとめて用いた.

沿岸域での調查を 1996 年 3 月から 1997 年 2 月に月 1 回

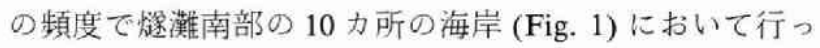
た。魚類の採集には 1 辺 $1.5 \mathrm{~m}$ の正三角形型の押し網（目 合い $1 \mathrm{~mm}$ )を用い, 1 定点あたり $50 \mathrm{~m}$ の採集を約 2 knot の速度で 3 回繰り返した。採集された魚類の種数, 生物量 が増加した春一夏期のうち，6月には先述の月例調査の定点 に 2 力所在追加して合計 12 力所の海岸老調查地とした.

これら 12 力所の海岸のうち, 調査区域の内部もしくは隣 接域にアマモ場屯しくはガラモ場が存在した 6 力所の海岸 を藻場区として扱い, 植生がみられない 6 力所の海岸（砂 浜区）との比較に供した。

漁港での調查を 1996 年 3 月から 1999 年 3 月に愛媛県西 条市河原津漁港 (水深約 2-5 m) において月 1-3 回の頻度で 行った. $300 \mathrm{~W}$ 水上灯を日没後 1 時間以上経過してから点灯 し, 魚類の採集を点灯開始 30 分後加ら 1 時間継続した. 2 種 類の手網(口径 $30 \mathrm{~cm}$, 目合い $2 \mathrm{~mm}$ および網口 $15 \times 12 \mathrm{~cm}$, 目合い $0.2 \mathrm{~mm}$ )により可能な限り多くの魚類を採集した。

いずれの調査においても, 得られた標本を $10 \%$ 海水木ル マリンで固定して持ち帰った。実験室において魚類を選別 し, 可能な限り細かい分類群まで同定した。

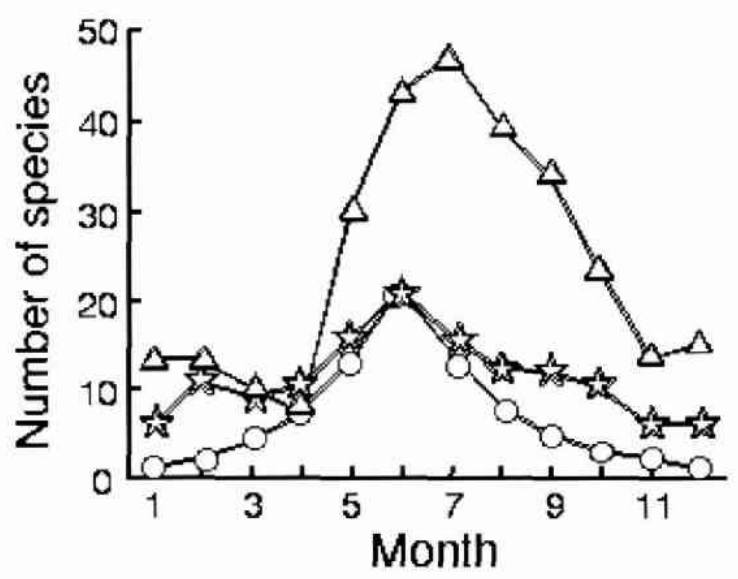

Fig. 2. Seasonal changes in number of fish species collected offshore (triangles), inshore (circles) and in a fishing port (asterisk).
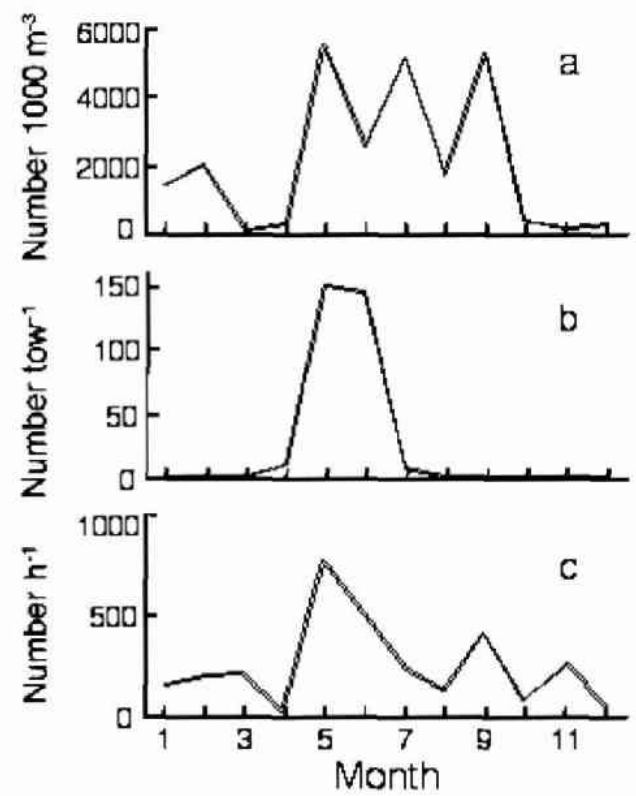

Fig. 3. Seasonal changes in number of fish $1,000 \mathrm{~m}^{-3}$ offshore (a), number of fish tow ${ }^{-1}$ inshore (b), and number of fish $\mathrm{h}^{-1}$ in a fishing port (c).

\section{結果}

沖合域, 沿岸域, 漁港における魚類の出現

沖合域では, 49 科 97 種以上, 合計 51,322 個体の魚類が 採集された。月ごとの出現種数は 7 種 (4月) から 47 種 (7 月)の間で変動した。平均個体数 $\left(1,000 \mathrm{~m}^{3}\right.$ あたり個体数 $)$ は 11 月，12月， 3 月および 4 月には 250 個体以下であった のに対し，5月，7月求よび 9 月には 5,000 個体を上回った (Fig. 2，3)。種数と個体数はともに5月から9月に多かっ た.

沿岸域では, 合計 24 科 38 種以上, 合計 9,521 個体の魚 類が採集された. 月ごとの出現種数は 1 種（12月と 1 月） から 21 種 (6月) の間で, 平均個体数 (1 曳網あたり個体 
Table 1. Comparison of dominant species of fish early life stages collected offshore, inshore and in a fishing port in the Sea of Hiuchi, the central Seto Inland Sea, where monthly collections of larval and juvenile fishes were conducted from 1996 to 1999.

\begin{tabular}{|c|c|c|c|c|c|c|}
\hline \multirow{2}{*}{ Species } & \multicolumn{2}{|c|}{ Offshore } & \multicolumn{2}{|c|}{ Inshore } & \multicolumn{2}{|c|}{ Port } \\
\hline & $\%$ & Rank & $\%$ & Rank & $\%$ & Rank \\
\hline Konosirus punktatus & 15.7 & 1 & 7.5 & 3 & 27.1 & 1 \\
\hline Sardinops malenostictus & 12.4 & 2 & & & & \\
\hline Ctenotrypauchen microcephalus & 11.6 & 3 & & & & \\
\hline Ammodytes personatus & 10.4 & 4 & & & & \\
\hline Decapterus maruadsi & 10.1 & 5 & & & & \\
\hline Apogon lineatus & 7.9 & 6 & & & & \\
\hline Tridentiger spp. & 7.1 & 7 & 0.4 & 9 & & \\
\hline Sardinella zunasi & 3.9 & 8 & & & 14.0 & 2 \\
\hline Amblychaeturichthys hexanema & 1.9 & 9 & & & & \\
\hline Repomucenus spp. & 1.5 & 10 & & & & \\
\hline Gymnogobius castaneus & & & 44.3 & 1 & & \\
\hline Chaenogobius annularis & & & 35.9 & 2 & & \\
\hline Acanthopagrus schlegelii & & & 5.7 & 4 & & \\
\hline Chaenogobius gulosus & & & 1.5 & 5 & & \\
\hline Takifugu niphobles & & & 0.7 & 6 & & \\
\hline Gobiidae spp. & & & 0.7 & 7 & & \\
\hline Gymnogobius heptacanthus & & & 0.6 & 8 & & \\
\hline Hyporhamphus sajori & & & 0.4 & 10 & 1.8 & 10 \\
\hline Pictiblennius yatabei & & & & & 12.1 & 3 \\
\hline Enedrias nebulosa & & & & & 10.9 & 4 \\
\hline Plecoglossus altivelis altivelis & & & & & 9.7 & 5 \\
\hline Omobranchus elegans & & & & & 8.6 & 6 \\
\hline Neoclinus bryope & & & & & 4.1 & 7 \\
\hline Pseudoblennius spp. & & & & & 2.1 & 8 \\
\hline Ernogrammus hexagrammus & & & & & 1.9 & 9 \\
\hline Leucopsarion petersi & & & & & 1.8 & 10 \\
\hline
\end{tabular}

数）は 0.03 個体（1月）から 150.0 個体（5月）の間で変動 した (Fig. 2, 3).

漁港においては，26科 44 種以上，合計 13,651 個体の魚 類が採集された. 月ごとの出現種数は 5 種 (11月) から 21 種 (6月), 平均個体数（1 時間あたり個体数）は 16.0 個体 (4月) から 767.5 個体（5月）の間で变動した (Fig. 2, 3).

\section{3つの生虫图における優占穆の比較}

3 つの生息圈 (沖合域, 沿岸域および漁港) のいずれにお いても優占種（個体数における上位 10 種）となったのはコ ノシロ (Konosirus punktatus) のみであった (Table 1).いず

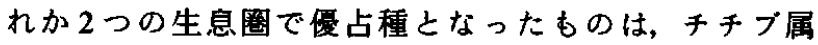
(Tridentiger spp.: 沖合域と沿岸域), サッパ (Sardinella zunasi: 沖合域と漁港), サヨリ (Hyporhamphus sajori: 沿岸 域と漁港）であった。優占種のほとんどは，いずれか $1 つ$ の生息圈においてのみ優占した，3つの生息圈 1 つの生息 圈のみで優占種となったものは以下のとおりであった．沖 合域のみで優占：マイワシ (Sardinops malenostictus), アカ ウオ (Ctenotrypauchen microcephalus), イカナゴ (Ammodytes personatus), マルアジ (Decapterus maruadsi), テンジ クダイ (Apogon lineatus), アカハゼ (Amblychaeturichthys hexanema), ネズッポ属 (Repomucenus spp.); 沿岸域のみ で優占：ビリンゴ(Gymnogobius castaneus), アゴハゼ
(Chaenogobius annularis), クロダイ (Acanthopagrus schlegelii), ドロメ (Chaenogobius gulosus), クサフグ (Takifugu niphobles), 八ゼ科 (Gobiidae spp.), ニクハゼ (Gymnogobius heptacanthus)；漁港のみで優占：イソギンポ (Pictiblennius yatabei), ギンポ (Enedrias nebulosa), アユ (Plecoglossus altivelis altivelis)，ナべカ (Omobranchus elegans)，コケギンポ (Neoclinus bryope), アナハゼ属 (Pseudoblennius spp.), ムズ ジガジ (Ernogrammus hexagrammus), シロウオ (Leucopsarion petersi).

\section{夏期の沿岸域における砂浜海岸と莎場の比艾}

砂浜区では合計 12 種, 藻場区では合計 14 種の魚類が採 集された．藻場区における 1 电網あたりの種数（士標準偏 差: $6.0 \pm 1.9)$ は砂浜区における值 $(2.7 \pm 2.2)$ に比べて有意 に大きかった $(U$-test, $p<0.05)$. 砂浜区と藻場区の両方に おいて優占したものは, コノシロ，アゴハゼ,クロダイ, ニクハゼ，ビリンゴ，八ゼ科 spp.であった．砂浜区におい てのみ優占したものはチチブ属 spp.,メナダ属 Chelon spp., サビハゼ (Sagamia geneionema), ウキゴリ, カマス属 (Sphyraena sp.), ミミズ八ゼ属 (Luciogobius sp.), 藻場区に おいてのみ優占したものはドロメ，サヨリ，アカハゼ, チ クゼン八ゼ (Gymnogobius uchidai), ヒゲ八ゼ (Parachaeturichthys polynema) であった (Table 2). 
Table 2. Comparison of dominant species of fish early life stages collected inshore in areas with and without vegetation in June, 1996.

\begin{tabular}{|c|c|c|c|c|}
\hline \multirow{2}{*}{ Species } & \multicolumn{2}{|c|}{ Without vegetation } & \multicolumn{2}{|c|}{ With vegetation } \\
\hline & $\mathrm{N} \%$ & Rank & $\mathrm{N} \%$ & Rank \\
\hline Konosirus punktatus & 56.1 & 1 & 5.9 & 4 \\
\hline Chaenogobius annularis & 16.5 & 2 & 68.5 & 1 \\
\hline Acanthopagrus schlegelii & 15.5 & 3 & 10.6 & 3 \\
\hline Tridentiger spp. & 7.8 & 4 & & \\
\hline Chelon spp. & 1.7 & 5 & & \\
\hline Sagamia geneionema & 0.7 & 6 & & \\
\hline Chaenogobius annularis & 0.5 & 7 & & \\
\hline Gymnogobius heptacanthus & 0.2 & 8 & 1.1 & 5 \\
\hline Gymnogobius castaneus & 0.2 & 8 & 0.6 & 7 \\
\hline Gobiidae spp. & 0.2 & 8 & 0.1 & 10 \\
\hline Sphyraena sp. & 0.2 & 8 & & \\
\hline Luciogobius sp. & 0.2 & 8 & & \\
\hline Chaenogobius gulosus & & & 11.9 & 2 \\
\hline Hyporhamphus sajori & & & 0.8 & 6 \\
\hline Amblychaeturichthys hexanema & & & 0.2 & 8 \\
\hline Gymnogobius uchidai & & & 0.2 & 8 \\
\hline Parachaeturichthys polynema & & & 0.1 & 10 \\
\hline
\end{tabular}

\section{考察}

\section{瀬戸内海中央部における魚類幼期個体の出現特性}

調查を行った 3 つ生息圈（沖合域, 沿岸域, 漁港) の いずれにおいても魚類の種数と個体数は春-夏期に最も多 く, 秋一冬期に少ないという傾向が認められた. 沿岸域にお ける個体密度は約 5,000 倍の大きな季節変動を示した。 春-夏期と秋一冬期の間で種数と個体数が大きく異なる現象 は, 大阪湾 (辻野ら 1995), 東京湾 (加納ら 2000), 有明海 （日比野ら 2002）であ報告されており, 内湾性浅海域に共 通した特性が瀬戸内海中央部における魚類群集の季節変化 にも備わっているすのと考えられる.

内湾域とは対照的に，外洋に面する沿岸域では，より多 くの種数の魚類が 1 年在通じて採集されることが報告され ている. 例えば, 土佐湾の砂浜海岸では冬期にも約 15 種の 魚類が出現する（木下 1984）。海域間での調查方法（採集 具) が異なるため直接比較はできないものの, 外洋に面す る土佐湾に比べて当海域における種数が少ないことの要因 としては, 瀬戸内海中央部では冬期の水温が $10^{\circ} \mathrm{C}$ 以下に低 下することや, 外洋から離れているために卵稚仔の供給を 受けにくいことが想定される（小路・田中 2002）.

\section{3 つの生息圈-沿岸域，沖合域，漁港の比較}

瀬戸内海中央部では, 沖合域, 沿岸域, 漁港のいずれに おいてあ八ゼ科とコノシロが高い割合で出現した。これは 先述した東京湾 (加納ら 2000), 有明海 (日比野ら 2002) などの仯泥底の海域における魚種組成と似通っており, 当 海域の底質環境（中央粒径值 6 以上の泥質堆積物; 日本海 洋学会沿岸海洋研究部会 1985）の特性を反映していると考

\section{えられる。}

沖合域, 沿岸域, 漁港の全てにおいてコノシロが, いず れか 2 つの生息圈においてチチブ属 spp., サッパ, サヨリ が優占種となったか，他の優占種（22 分類群）は全て沖合 域, 沿岸域, 漁港のうちいずれか 1 つの生息圈において優

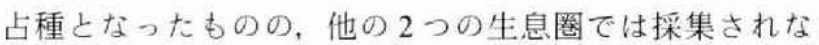
かったか, 採集数か極めて少なかった。これらの結果は, 瀬戸内海の浅海域において優占する魚種の多くがそれぞれ 異なった幼期の生息圈をむつことを示すものと考えられ る.

\section{沿岸域の 2 つの生息圈-砂浜と藻場の比較}

沿岸域では植生の有無により夏期の魚種組成が異なるこ とむ明らかとなった。いずれかの区において優占種となっ た 17 種のうち, 両区に共通した優占種は 6 種であり, 他の 11 種は一方の区において優占種となったものの, 他方の区 では採集されないか，採集数が極めて少なかった，本結果 は, 水深が約 $1 \mathrm{~m}$ 末満という沿岸域の限られた空間におい てち，そこに生息する魚類幼期個体の種組成に植生の有無 が強く影響することを示している. 先述の 3 つの生息圏 （蚛合域, 沿岸域, 漁港) 間での魚種組成の違いに加えて, 沿岸域に抢ける植生の有無による魚種組成の違いは, 異な る生息環境在包括的に保全することが瀬戸内海中央部浅海 域の魚類全体の生産性の向上や持続的利用にとって重要で あることを示していると考える。

藻場区においては砂浜区に比へて出現した魚類の種数が 多かった．藻場は魚類の生息環境の構造を複雑にすること や, 多樣な䭒料生物を供給することを通じて, 魚類幼期個 体に上っての被食シェルター, 摄慨場および高い生産の場 としての機能を有するものと考えられている（布施 1981; 
大野 1981). 本研究における沿岸域での調查は仔稚魚期の 魚類を主対象とし夏期のみに行われたちのである. より大 型の魚類を捕獲できる採集具等を使用した周年調查を実施 することにより，藻場の魚類成育場としての諸機能を，上 り普遍的かつ定量的に評価することが今後の課題である.

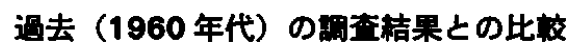

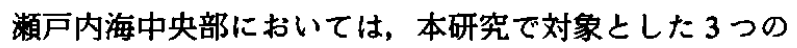
生息圈のうち沖合域において 1960 年代に同様の調査が行 われている (岡山県水産試験場 1964). 過去の調查では, 燧 灘に隣接する備譛瀬戸も調査海域に含まれていることと, 仔稚魚の採集に用いたネットの口径 $(0.715 \mathrm{~m})$ が小さい点 において本研究と採集方法が異なるものの, 種組成を比較 する資料として用いることにより，以下に述べるような共 通点・相連点が認められる.

両年代の調查においてイカナゴ，マルアジ，ネズッポ属 spp. が共通の優占種であった. しかし，このうちイカナゴ の個体数割合は 1960 年代 $(29.0 \%)$ に比べて 1990 年代 (10.4\%)に低かった。逆に 1960 年代に $1.7 \%$ 以下であった コノシロおよびマイワシが 1990 年代の調查ではそれぞれ $15.7 \%$ および $12.4 \%$ を占め優占種となった（小路ら 2002）. 過去の調查結果との間での定量的比較は不可能であるが, 当海域におけるこれら小型多獾性魚類の種構成が大きく変 化したことが, 幼期個体の種組成に認められた年代間の差 に反映されているものと考えられる。

貄 一連の調查を進めるにおたり，愛媛県中予水産試験場 東予分場の伊藤捷久分場長, 前原務主任研究員(いずれむ当 時), および歴代の同場職具の皆様より多大なご支援・ご協力を睗 りました，厚く御礼申し上げます，原稿に建設的なご意見をいた だいた匿名の 2 名の査読者に深謝します.

\section{引用文献}

東 幹夫 1981. 稚魚成育場としてのアマモ場の役割. 日本水産学 会 (編)，藻場・海中林，恒星社厚生閣，東京，pp. 34-56.

布施慎一郎 1981.メバルとアマモ場・ガラモ場との関係. 日本水 産学会 (編), 落場・海中林, 厚生社厚生閣, 東京, pp. 24-33.

日比野 学・太田太郎・木下 泉・田中 克 2002. 有明海湾奥部 の干潟汀線域に出現する仔稚魚. 魚類学雑誌, 49: 109-120.

環境庁 1998. 第 5 回自然環境保全基磁調查 海辺調查 総合報告 書. 環境庁, 東京, pp. 1-83.

加納光樹 - 小池 哲 - 河野 博 2000 . 東京湾内湾の干潟域の魚類 相とその多様性. 魚類学雑誌, 47: 115-129.

木下 泉 1984. 土佐湾の砕波帯における稚仔魚の出現. 海洋と生 物, 35: 409-415.

日本海洋学会沿岸海洋部会 1985. 瀬戸内海 I, II. 日本全国沿岸海 洋誌 (編), 日本全国沿岸海洋誌, 東海大学出版会, 東京, pp. 607-707.

風市友利・小森星児・中西弘 1996. 瀬戸内海の生物資源と環境, 怛星社厚生閣, 東京, $272 \mathrm{pp}$.

岡山県水産試験場 1964. 瀬户内海中央部における卵・稚魚の出現 とその生態-幼稚魚生態調查報告書. 岡山県水産試験場, 岡山, 85 pp.

大野止夫 1981. ガラモ場内の環境. 日本水産学会 (編), 藻場・海 中林, 厚生社厚生閣, 東京, pp. 75-92.

小路 淳 2000. 瀬戸内海中央部の一漁港において奵火採集により 得られた魚類幼稚仔. 南紀生物, 42: 119-122.

小路 淳・田中 克 2002. 瀬戸内海中央部㮸灌の䂽波帯において 採集された魚類稚仔. 水産增殖, 50: 123-128.

小路 淳 - 前原 務・武智昭彦 - 谷川貴之 - 村田憲之 - 田中 克 2002. 瀬戸内海中央部の燧灘において採集された仔稚魚. 日本 水産学会誌, 68: 835-842.

辻野耕實・安部恒之・日下部敬之 1995. 大阪湾南部砕波帯に出現 する幼稚仔魚. 大阪府立水産試験場研究報告, 9: 11-32.

Yamamoto, M. and O. Tominaga 2005. Feeding ecology of dominant demersal fish species Favonigobius gymnauchen, Repomucenus spp. and Tarphos oligolepis at a sandy beach where larval Japanese flounder settle in the Seto Inland Sea, Japan. Fisheries Science, 71: 1332-1340. 